family become a reflection of each other. That is why the image of Ukraine, how it emerges in the poet's intimate lyrics, the demonstration of the moral model of the attitude towards a woman, family and personality as a whole, formed on the emotional, sensual level the ground that led in the times of life of T.G. Shevchenko and the further history of Ukraine, to the focus of intellectual searches, the efforts of researchers of the K obzar heritage in order to develop the philosophy of the $U$ krainian idea.

Keywords: existence, freedom, present and unreal existence, care, internal and external conflict, the search for ways to choose self-realization in society.

DOI: https://doi.org/10.31392/NZ-npu-142.2019.14

УДК 7.071.2:784

Ладний А. С., Кедіс О. Ю.

\title{
КОМУНІКАТИВНІ АСПЕКТИ ДІЯЛЬНОСТІ ХОРОВОГО ДИРИГЕНТА
}

У статті аналізуються ті завдання, щзо постають перед хоровим диригентом. Визначено комунікативний характер даного типу виконавської діяльності. Музичний твір розгортається у часі та наповнюється сенсом, якщо він отримує вірного прочитання з боку виконавців та передається слухачам. Підкреслено багатовекторність комунікації, яка здійснюється диригентом у ході знайомства з музичним твором, його аналізом, розробкою, виконанням. Зазначено, щуо при виконанні обробок народних пісень відбувається створення додаткових сенсів, що потребують свого розшифрування. Наголомено на визначній ролі жесту та міміки як універсальних засобів спілкування між диригентом та виконавським колективом. Завдяки налаштованості виконавців-хористів до співдії буде досягатися комунікація, коли найменша зміна нюансування буде передаватися від диригента до виконавців. Сднання диригента та виконавського колективу в емоційно-творчому пориві є запорукою плідної співдї, результатом якої стає донесення твору до слухача.

У статті висвітлено особливості комунікаиії, яку здійснює хоровий диригент при роботі над музичним твором, його виконанні та взаємодії з учасниками творчого прочесу.

Диригент є виконавцем, чия діяльність за своєю сутністю має комунікативний характер. Специфіка його комунікаиї пов'язана з роботою над музичним твором, який виступає своєрідним смислоутворюючим містком до композитора. У разі виконання обробки народної пісні перед диригентом постає більш складне завдання, адже додається завдання розшифрування тих кодів, що закладені у фольклорному першоджерелі. Неодмінною частиною комунікативного процесу, який здійснює диригент, є робота з колективом виконавиів, яка впроваджується завдяки таким засобам, як жест та міміка. Подальша експлікація комунікативної теорії по відноченню до різних сфер виконавської музичної діяльності уявляється перспективним напрямком.

Ключові слова: хоровий диригент, виконавець, комунікачія, творчість, обробка.

Діяльність хорового диригента включає чимало завдань. Це і знання музичного матеріалу, вміння опрацьовувати нові твори, робота з виконавцями, навички аранжування народнопісенного матеріалу - це не повний перелік того, що має вміти хормейстер. Разом з тим, провідне значення має здатність бути частиною комунікативного процесу, який розгортається між усіма учасниками 
спілкування за допомогою музики. Виокремлення специфіки становлення профресійного виконавського рівня диригента $\epsilon$ актуальним питанням, вирішення якого сприятиме вирішенню завдання практичного рівня.

При аналізі діяльності музиканта-виконавця необхідним $€$ аналіз загальних питань, пов'язаних з естетичним виміром мистецьких явищ. Цей зріз проблематики представлений в праці А. Канарського. Комунікативне значення фольклору окреслюється в роботі А. Іваницького. Актуальні розробки, де окреслюються такі ключові для диригента поняття, як “жест" та "міміка", наявні в статтях сучасних авторів Л. Іконнікової та М. Кревсун. Міркування, пов'язані 3 професією диригента та певні теоретичні висновки стосовно неї представлені в статтях таких авторів, як Д. Івен та В. Фуртвенглер.

При аналізі музичного твору, варто звертати увагу не лише на його мистецько-художні характеристики, але й на те, що твір виступає в якості повідомлення, частини комунікативного акту. У разі виконання хорового твору необхідно розглянути роль диригента у комунікації, що здійснюється за його участі. Це питання не знайшло достатнього висвітлення в музикознавчій літературі, що й обумовлює звернення до неї в рамках статті.

Метою cmammi є висвітлення особливостей комунікації, яку здійснює хоровий диригент при роботі над музичним твором, його виконанні та взаємодії з учасниками творчого процесу.

Музичний твір виступає складним утворенням, природа якого пов'язана 3 різними суб'єктами. Твір є одиницею значення про ту добу, в яку він був написаний, він відображає особливість творчого мислення композитора. Він виступає повідомленням, яке має потрапити до свого адресата - слухача. Проте специфіка музичного мистецтва $€$ набагато складніша, ніж в ряді інших видів мистецтва. Музика має часову природу. Музичний твір розгортається у часі та наповнюється сенсом, якщо він отримує вірного прочитання з боку виконавців та передається слухачам.

Д. Івен зазначав, що майстерність диригента полягає у вмінні оперувати 3 двома групами - виконавцями та публікою. Причому диригент виступає в якості універсального посередника між ними. 'Диригент пов'язаний безпосередньо не з інструментом, а з двома групами людей, на які спрямована його воля. Його мистецтво полягає в тому, щоб перетворити першу групу у вібруючий інструмент, що звучить так, ніби він грає на ньому не умовно, а власними руками, другу ж групу - публіку - диригент прагне перетворити на єдиного слухача" [1, с. 276]. Це твердження надзвичайно добре відображає сутність майстерності диригента як виконавця. Але якщо мова йде про хоровий твір, а особливо про обробку народної пісні, шлях до слухача буде більш складним. Насамперед, при зверненні до жанру обробки кожен композитор має справу $з$ твором, що $\epsilon$ результатом колективної творчості, автором якого $\epsilon$ народ. Чималу роль фрольклору, його ролі для розвитку національної свідомості приділяли такі музикознавці як В. Гошовський, А. Іваницький та інші дослідники.

А. Іваницький відзначав, що фрольклор $є$ явищем, яке безпосередньо пов'язане з мовою, музикою та власне мисленням. Необхідною умовою для його розуміння $є$ “історичний синтаксис музичного фрольклору", адже зараз можна казати про формування нового напрямку музикознавства, метою якого буде розшифрування, розкриття сенсів, власне винайдення кодів до розуміння 
музично-історичної інформації. “Ця інформація поки що розшифрована лише на кілька відсотків, вона міститься в музичному фольклорі, перейшовши у нього з первісного мистецтва, і поринає вглиб минулого на сорок тисяч років. Отже, музичний фольклор - це та ланка, яка поєднує далеке минуле людства з сучасністю. Самопізнання людини не буде дієвим без проникнення у палеопсихологію, а один із шляхів такої трансмісії - наукове декодування фольклорної інформації, а також виховання почуттів на фольклорних текстах і мелодіях" [3, с. 4]. В цьому твердженні підкреслюється значення фольклору, як такого, що має неминучу цінність.

Отже, при здійсненні обробки народної пісні аранжувальник повинен обрати для себе стратегію перетворення:

1) своєрідне укрупнення фольклорного твору, коли його сутнісні риси залишаються незмінними, а збільшується кількість учасників та більш опуклими постають певні риси;

2) розкриття внутрішніх сенсів, які іманентно були присутні в творі, що може реалізовуватися шляхом повторення та нашарування різноманітних ліній, які закладені в народному джерелі;

3) обрамлення пісні іншим новим матеріалом, коли фрольклорне джерело може виступати своєрідним носієм національного, культурно-історичного начала. В даному випадку авторський матеріал може носити різко протилежний характер та виступати уособленням духу сьогодення -виступати зразком залучення новітніх технік композиції, конструктивного начала, втіленням суб'єктивного начала та ін.

При роботі над обробкою диригент повинен віднайти вірний шлях до розуміння авторського задуму. Тобто він вступає у комунікацію з композитором та прагне прочитати сутність його трансформацій першого початкового фольклорного твору. Загальновідомо, що провідною рисою композиторської творчості останніх століть виступає шлях винайдення власного неповторного методу, стилю, який би був достатньо пізнаваним та таким, що значно відрізнятиме його від інших. Вирішення даної мети пов'язане досить часто 3 відкиданням усього типового, раціонального та характерного для минулих музичних практик. Проте такі жанри, як варіації та обробки, не втрачають своєї актуальності, адже вони виступають своєрідним дороговказом для усвідомлення задуму композитора.

Зауважимо, що власний виконавський підхід хормейстера може відрізнятись від авторського. Оскільки музичний досвід, як і будь-яка форма естетичного досвіду, має індивідуально-забарвлений характер, сприйняття твору може відрізнятися та справляти різний естетичний вплив. А. Канарський відзначав складну чуттєву природу людини, вказуючи на те, що жодний стан душі не може вважатися відірваним від інших. "Складний та багатогранний людський чуттєвий стан. Але у процесі, в живій зміні цих станів достатньо чітко простежується і стійка здатність їх прояву. Але жоден з таких станів не може бути абсолютно відірваним від іншого. В кожному з них викарбовується в певна міра небайдужості людини до предмету діяльності, і така ж міра небайдужості їі до самої себе, до свого цілісного уявлення про життя, сенс людського буття" [4, с. 11]. Відповідно, сприйняття твору диригентом буде залежати від його естетичного базису. Власне, чималу роль будуть відігравати інтонаційний 
словник, як індивідуальний так і епохи. Ця інтонаційна природа музики підкреслювалась Б. Асаф'євим та відзначалась А. Канарським. “Живою серцевиною музики $є$ все багатство інтонаційних відношень. Там, де мало місце збайдужіння таких стосунків, там збайдужінню підлягала й інтонаційна сорера їх виявлення. I якщо суперечити тут тому метафрізичному уявленню, начебто музика повинна своїм існуванням лише "чутному" як такому, то ми могли б сказати, що, навпаки, вона завжди протистояла цьому "чутному", вона ніби могла проявлятися по-буденному, монотонно та т.п." [4, с. 360]. Відповідно, на думку Канарського, музичні твори спрямовані на те, щоб протистояти збайдужінню людини щодо суспільного, тобто вона має долучатися до комунікації, як і у вербальній мові, через рух інтонацій.

Коли мова йде про хоровий твір, у процес комунікації долучається не лише "розмова" диригента та композитора. Виконання передбачає звернення до вокального колективу, що, хоча й $є$ спільнотою різних особистостей, проте має демонструвати єдину мисленнєву лінію, виступати в якості єдиного живого організму, що є своєрідним інструментом, який діє під керівництвом диригента. Комунікація хору та диригенту протікає на різних рівнях. Якщо під час роботи над музичним твором можливе задіяння вербальних фрорм спілкування, то при виконанні використовується виключно комунікація із застосуванням жестів, міміки.

В. Фуртвенглер відзначав у праці “Проблема диригування", що при роботі диригента 3 колективом надзвичайно важливим $\epsilon$ єдине емоційне налаштування, коли музиканти не керуються виключно вказівками, а й відчувають їх необхідність. “Чим менше кожний окремий музикант співдіє в єдиному творчому процесі, тим в більшій мірі задумані диригентом агогічні, динамічні нюанси і т.д. або зовсім не виконуються, або досягаються за допомогою багатьох репетицій, нескінченної муштри. Але найбільш важливе і краще - як, наприклад, ледь помітна змінність темпу, фарб - залишаються при цьому недосяжними. В кінці кінців диригент часто стоїть перед вибором: або перебільшення, або повна відмова від своїх намірів інтерпретатора" [6, с. 398]. Тобто мова йде про здатність виступати єдиним організмом, де немає свавілля кожного музиканта, але, разом з тим, $є$ можливість приймати участь у процесі створення художнього цілого. Саме шляхом налаштованості виконавцівхористів до співдії, буде досягатися комунікація, коли найменша зміна нюансування буде передаватися від диригента до виконавців.

Якщо розглянути відомих диригентів, що керують оркестром, та хормейстерів, можна виділити дві групи майстрів. Одні з них володіють певною універсальністю, вміючи налаштуватись на виконання творів будь-яких композиторів. Інші ж, обирають твори певних композиторів, чи конкретноісторичної доби чи стильового спрямування. Вони не володіють здатністю в рівній мірі працювати з творами, що належать до різних епох. 3 погляду майстерності, подібну тенденцію можна сприймати по-різному. Це може свідчити про те, що диригенти більше надають перевагу окремим творам, які можуть більше впливати на їх емоційну складову. Проте з погляду комунікативного підходу, можна зазначити, що, при виборі конкретних творів чи композиторів, диригент не досяг точки спілкування, не вступив у комунікацію.

Якщо ж звернутись власне до тих шляхів, за допомогою яких досягається 
комунікація диригента та хору, то звісно, найбільшу роль відіграють міміка та жести. Розділяємо думку М. Кревсун стосовно значення міміки в діяльності хорового диригента: “Міміка, будучи важливим компонентом диригентського апарату хормейстера, поряд з мануальної технікою, значно впливає на всі сторони виконавського процесу. Здійснюючи комунікативну і естетичну функції, вона забезпечує інформаційний простір хорового виконання (репетиційного і концертного) двостороннім невербальним зв'язком (від диригента до хору і назад), в результаті якої народжуються і єдиний колективний задум, і єдиний емоційний настрій хорового колективу, і єдині засоби реалізації" [5, с. 437-438]. Відповідно, під мімікою варто розуміти сукупність рухів частин особи, які $\epsilon$ наслідком її реакції на різні зовнішні впливи. У випадку диригента, міміка відіграє роль скоріше емоційної реакції на ті події, які мають відбуватися в музичному тексті. М. Кревсун виділяє два типи хорових диригентів, які розрізняються за ступенем активності міміки - імпульсивні натури, з яскравою лицьовою мімікою та диригенти зі стриманим вираженням емоцій, але великою внутрішньою експресією. Виразність виступає найважливішим чинником здійснення комунікації між керівником і хористами.

Окрім комунікації диригента та музикантів важливим $€$ його спілкування 3 публікою. Якщо міміка залишається поза можливістю бути сприйнятою глядачами, то диригентський жест є чинником, що покращує розуміння його виконавської інтерпретації, сприяє налаштованості на сприйняття. Л. Іконнікова відзначає надзвичайну інфрормативність жесту диригента, яка може бути сприйнята як виконавцями, так і публікою. "Інтерпретуючий жест, який перекодовує для свого специфічно диригентського простору знаковий простір нотного тексту і з допустимо вичерпною повнотою настільки ж переконливо буде транслювати художні наміри артистам хору, може бути однаково переконливим як для сприймаючих його професійну грань виконавців, так і для необізнаного в професійних тонкощах слухача" [2, с. 64].

Диригент $€$ виконавцем, чия діяльність за своєю сутністю має комунікативний характер. Специфріка його комунікації пов'язана з роботою над музичним твором, який виступає своєрідним смислоутворюючим містком до композитора. У разі виконання обробки народної пісні перед диригентом постає більш складне завдання, адже додається завдання розшифрування тих кодів, що закладені в фольклорному першоджерелі. Неодмінною частиною комунікативного процесу, який здійснює диригент, $€$ робота 3 колективом виконавців, яка впроваджується завдяки таким засобам, як жест та міміка. Подальша експлікація комунікативної теорії по відношенню до різних сфер виконавської музичної діяльності уявляється перспективним напрямком.

\section{Використана література:}

1. Ивен Д. Человек с палочкой. Дирижерское исполнительство. Практика. История. Эстетика. Москва : Музыка, 1975. С. 276-279.

2. Иконникова Л. Семиотические ресурсы интерпретирующих жестов хорового дирижера. Bonpocbl музыкального исполнительского искусства. Серия 5. Bопросы теории и истории исполнительского искусства. Музыкальная педагогика. Минск: УО “Белорусская государственная академия музыки", 2015. Вып. 36. С. 56-68.

3. Іваницький А. I. Український музичний фольклор : підручник для вищих учбових закладів. Вінниця : НОВА КНИГА, 2004. 320 с. 
4. Канарский А. С. Диалектика эстетического процесса. Київ : ЗАО “Мироновская типография", 2004. $378 \mathrm{c.}$

5. Кревсун М. В. Мимика как компонент дирижерского аппарата и хоровой коммуникации. Вестник Таганрогского института имени А. П. Чехова. Таганрог, 2010. № 2. С. 437-444.

6. Фуртвенглер В. Проблема диригування. Дирижерское исполнительство. Практика. История. Эстетика. Москва : Музыка, 1975. С. 398-400.

\section{References:}

[1] Iven, D. (1975). Chelovek s palochkoj. Dirizherskoe ispolnitelstvo. Praktika. Istoriya. Estetika. M oskva : M uzyka, S. 276-279.

[2] Ikonnikova, L. (2015). Semioticheskie resursy interpretiruyushih zhestov horovogo dirizhera. Voprosy muzykalnogo ispolnitelskogo iskusstva. Seriya 5. Voprosy teorii i istorii ispolnitelskogo iskusstva. M uzykalnaya pedagogika. M insk : U O "B elorusskaya gosudarstvennaya akademiya muzyki", Vyp. 36. S. 56-68.

[3] Ivanytskyi, A . I. (2004). Ukrainskyi muzychnyi folklor : pidruchnyk dlia vyshchykh uchbovykh zakladiv. Vinnytsia: NOVA KNY HA, 320 s.

[4] Kanarskij, A. S. (2004). Dialektika esteticheskogo processa. K iyiv : ZAO “M ironovskaya tipografiya”, $378 \mathrm{s.}$

[5] K revsun, M. V. (2010). M imika kak komponent dirizherskogo apparata i horovoj kommunikacii. Vestnik Taganrogskogo instituta imeni A. P. Chehova. Taganrog, № 2. S. 437-444.

[6] Furtvengler, V. (1975). Problema diriguvannya. Dirizherskoe ispoInitelstvo. Praktika. Istoriya. Estetika. M oskva : M uzyka, S. 398-400.

\section{ЛАДНЫЙ А. С., КЕДИС О. Ю. Коммуникативный аспект деятельности хорового дирижера. \\ В статье анализируются те задачи, которые стоят перед хоровым дирижером.} Отмечен коммуникативньй характер данного типа исполнительской деятельности. Музыкальное произведение разворачивается во времени и наполняется смыслом, если оно получает верное прочтение со стороны исполнителей и передается слушателям. Подчеркнута многовекторность коммуникации, которая осуществляется дирижером в ходе знакомства с музыкальным произведением, его анализом, разработкой, исполнением. Отмечено, что при исполнении обработок народных песен происходит создание дополнительных смыслов, требуюших расшифровки. Отмечена важнейшая роль жеста и мимики как универсальных средств общения между дирижером и исполнительским коллективом. Благодаря настроенности исполнителей-хористов на сотворчество, будет достигаться коммуникация, когда малейшее изменение нюансировки будет передаваться от дирижера до исполнителей. Единение дирижера и исполнительского коллектива в эмочионально-творческом порыве является залогом плодотворной совместных действий, результатом которых становится донесение произведения до слушателя.

В статье освещень особенности коммуникации, которую осуществляет хоровой дирижер при работе над музыкальным произведением, его исполнении и взаимодействия с участниками творческого прочесса. Дирижер является исполнителем, чья деятельность по своей сути имеет коммуникативный характер. Специфика его коммуникации связана с работой над музыкальным произведением, которое выступает своеобразным смыслообразуюшим мостиком к композитору. В случае выполнения обработки народной песни перед дирижером встает более сложная задача, ведь добавляется задача расшифровки тех кодов, которые заложены в фольклорном первоисточнике. Непременной частью коммуникативного процесса, который осуществляет дирижер, является работа с коллективом исполнителей, которая внедряется благодаря таким средствам, как жест и мимика. Дальнейтая экспликация коммуникативной теории по отномению к различным сферам исполнительской музыкальной деятельности представляется перспективным направлением.

Ключевые слова: хоровой дирижер, исполнитель, коммуникация, творчество, обработка. 
LADNYI A. S., KEDIS O. YU. Communicative aspects of the activity of the chore conductor.

The aim of the article is analyzes the tasks that have the choral conductor. The communicative nature of this type of performing activity was noted. The musical work unfolds in time and is filled with meaning if it gets a true reading from the performers and is passed on to the listeners. The multi-vector communication, which is carried out by the conductor in the course of acquaintance with the musical work, its analysis, development, execution is underlined. It is noted that when performing the processing of folk songs, additional meanings are created that require decoding. The most important role of the gesture and facial expressions as universal means of communication between the conductor and the performing collective was noted. Thanks to the mood of the performers-choir artists for cocreation, communication will be achieved when the slightest change in the nuances will be transferred from the conductor to the performers. The unity of the conductor and the performing collective in the emotional and creative impulse is the guarantee of fruitful joint actions, the result of which is the communication of the work to the listener.

The article highlights the features of communication that the choir conductor carries out when working on a musical work, its performance and interaction with participants in the creative process. The conductor is a performer whose activities are inherently communicative in nature. The specifics of his communication is associated with work on a musical work, which acts as a kind of semantic forming bridge to the composer. In the case of performing the processing of a folk song, the conductor faces a more difficult task, because the task of decoding those codes that are in the folklore source is added. An indispensable part of the communicative process conducted by the conductor is the work with the team of performers, which is implemented thanks to such means as a gesture and facial expressions. $\mathrm{F}$ urther explication of communicative theory in relation to various areas of performing musical activity seems to be a promising direction.

Keywords: choral conductor, performer, communication, creativity, processing.

DOI: https://doi.org/10.31392/NZ-npu-142.2019.15

УДК 378.015.3.046_021.66:811.111

Лобачук I. M.

\section{ПСИХОЛОГО-ПЕДАГОГІЧНІ УМОВИ ЕФЕКТИВНОГО ПРОФЕСІЙНО ОРІЄНТОВАНОГО НАВЧАННЯ ІНОЗЕМНОӤ МОВИ СТУДЕНТІВ МАГІСТРАТУРИ}

У статті розглядаються психолого-педагогічні умови, за допомогою яких відбувається ефективне навчання англійської мови студентів магістратури в процесі професійно орієнтованої підготовки, розглянуто сучасні підходи, комунікативний та ситуативний методи навчання англійської мови. Доведено, щзо забезпечення відповідних психолого-педагогічних умов дає змогу досягти продуктивних результатів у навчальній діяльності з розвитку іншомовної комунікативної компетентності магістрантів, визначити иляхи оптимізачії та інтенсифікації навчального процесу.

Навчання студентів іноземної мови в прочесі професійно орієнтованого навчання вимагає забезпечення психолого-педагогічних умов, які сприяють ефективному навчанню, впливають на досягнення гарних результатів та розвиток іншомовної комунікативної компетентності магістрантів.

Для того щоб викладання мови представляло справжню зміну не тільки в теорії, а й в процесі навчання, реформа цүілей, матеріалів та оиінки є недостатньою. Необхідно приділяти 